CZASOPISMO INŻYNIERII LA¿OWEJ, ŚRODOWISKA I ARCHITEKTURY JOURNAL OF CIVIL ENGINEERING, ENVIRONMENT AND ARCHITECTURE JCEEA, t. XXXIII, z. 63 (2/I/16), kwiecień-czerwiec 2016, s. 401-412

\author{
Anna BAZAN-KRZYWOSZAŃSKA ${ }^{1}$ \\ Maria MRÓWCZYŃSKA ${ }^{2}$ \\ Marta SKIBA $^{3}$
}

\title{
CHŁONNOŚĆ TERENÓW ZIELENI W MIEŚCIE - STUDIUM PRZYPADKU MIASTA ZIELONA GÓRA
}

\begin{abstract}
Artykuł przedstawia próbę zwrócenia uwagi na brakujące standardy urbanistyczne dla terenów miejskich. Przeanalizowano aktualne wskaźniki do szacowania chłonności terenu niezbędnego do programowania ogólnodostępnych terenów wypoczynkowych. Przedstawiono studia literaturowe nad wskaźnikami chłonności zagospodarowania terenu, służące ustaleniu relacji pomiędzy intensywnością i gęstością zabudowy wokół powierzchni biologicznie czynnych - lasów, parków i zieleńców. Zaprezentowano również możliwości wykorzysta modelowania z wykorzystaniem sztucznych sieci neuronowych dla oceny chłonności i pojemności terenów miejskich. W artykule zaprezentowane zostały podstawy teoretyczne, możliwe do wykorzystania w pracach doświadczalnych, pomocnych w określeniu czynników i elementów wpływających na uwarunkowania urbanistyczne. Badanie chłonności terenów zieleni w miastach przyczynia się do zachowania różnorodności biologicznej w granicach środowiska zurbanizowanego miast. Artykuł może pomóc zidentyfikować problemy w prowadzeniu polityki zrównoważonego rozwoju w miejskich obszarach funkcjonalnych. Zapis urbanistyczny w lokalnych dokumentach planistycznych tj studium uwarunkowań i kierunków zagospodarowania przestrzennego gminy czy miejscowym planie zagospodarowania przestrzennego, powinien wyróżniać i chronić tereny zieleni miejskiej z uwzględnieniem granic ich chłonności i pojemności. Konieczność monitoringu i kontroli polityki zagospodarowania przestrzennego mimo, że wymuszona ustawowo w ramach ustaleń ustawy z dnia 27 marca 2003 roku o planowaniu i zagospodarowaniu przestrzennym, nie wskazuje jednolitego zestawu wymaganych standardowych wskaźników urbanistycznych, które umożliwiłyby jakiekolwiek bilansowanie wartości w jednostkach przestrzennych. Widoczna jest potrzeba ujęcia ich w spójnym i kompletnym zbiorze regulacji.
\end{abstract}

Słowa kluczowe: pojemność, koncentracja, wskaźniki urbanistyczne, miasto, sztuczne sieci neuronowe

\footnotetext{
${ }^{1}$ Autor do korespondencji / corresponding author: Anna Bazan-Krzywoszańska, Uniwersytet Zielonogórski, wydział Budownictwa, Architektury i Inżynierii Środowiska, ul. prof. Z. Szafrana 1, 65516 Zielona Góra; tel. 6832826 39; A.Bazan@aiu.uz.zgora.pl

${ }^{2}$ Maria Mrówczyńska, Uniwersytet Zielonogórski, Wydział Budownictwa, Architektury i Inżynierii Środowiska, ul. prof. Z. Szafrana 1, 65-516 Zielona Góra; tel. 68328 26 36; M.Mrowczynska@ib.uz.zgora.pl

${ }^{3}$ Marta Skiba, Uniwersytet Zielonogórski, Wydział Budownictwa, Architektury i Inżynierii Środowiska, ul. prof. Z.Szafrana 1, 65-516 Zielona Góra; tel. 6832823 09; m.skiba@aiu.uz. zgora.pl
} 


\section{Wprowadzenie}

W trwałym i zrównoważonym rozwoju pojęcie dobrobytu mierzy się skalą posiadania zasobów kulturowych, przyrodniczych, a w dalszej konsekwencji posiadania kapitału społecznego i kulturowego, które determinują przetrwanie cywilizacji nie tylko w skali lokalnej, ale również w skali globalnej. Odnoszą się one do zwartego fizycznie układu przestrzennego oraz zwartego funkcjonalnie obszaru codziennej aktywności mieszkańców (gęstość zdarzeń przestrzennych).

Ostatnia dekada to okres gwałtownego rozwoju polskich miast. O podaży funkcji i usług miastotwórczych decyduje cena dzierżawy lokalu, co skutkuje tym, że z centrów polskich miast w zastraszającym tempie znika życie. Rozwiązanie problemu nie musi być skomplikowane. Najważniejszą zmianą jest wprowadzenie sztywnych granic wzrostu miasta i uzależnienie ich zasięgu od wyposażenia w infrastrukturę transportu publicznego, wodno-kanalizacyjną czy gazową. Wprowadzenie katastru ułatwiłoby wyznaczenie granic urbanistycznych. $\mathrm{W}$ granicach wzrostu miasta zobowiązuje ona do zagospodarowania posiadanej działki (inwestycja jest nagradzana przez system podatkowy) [1].

Zauważone tendencje potwierdzają wnioski z Analizy stanu i uwarunkowań prac planistycznych w gminach w 2013 roku, wg Śleszyńskiego "(...) narasta presja inwestycyjna lub nadpodaż odralnianych gruntów w strefach zewnętrznych miast, także tych mniejszych. Do tego powszechne jest zjawisko przeznaczania zbyt dużego udziału terenów pod zabudowę, głównie jednorodzinną. Jako wyraźnie najbardziej zagrożone kształtowaniem przestrzeni na mocy decyzji o warunkach zabudowy ujawniają się obecnie:

- gminy o intensywnych funkcjach rolniczych;

- gminy ekstensywnie zagospodarowane (funkcje leśne i ochrony przyrody);

- strefy podmiejskie ośrodków subregionalnych.

W podziale według typów gmin można też wprawdzie wskazywać na ogólnie pożądany kierunek porządkowania sytuacji planistycznej i pragmatyzm samorządów, jakkolwiek tempo tych zmian nie jest satysfakcjonujące. W tym kontekście można podtrzymać tezę, że aktualna polityka wspiera dalszą żywiołową, niekontrolowaną suburbanizację i chaos przestrzenny (...)" [2].

Środowisko architektów i urbanistów również dostrzegło istniejący problem, czego dowodem są opracowywane dokumenty. "Brak właściwych parametrów określających przestrzenne minima zdrowotne i społeczne powoduje nadużycia - realizację zespołów mieszkaniowych bez dostępu do komunikacji publicznej, szkół, przedszkoli, zieleni i sportu. Domy mieszkalne budowane są w nadmiernym zacieśnieniu i często w szkodliwym sąsiedztwie. (...) Odpowiednie warunki życia (zarówno zdrowotne, jak i społeczne) powinny być zapewnione przez obligatoryjne stosowanie standardów zawierających aspekty: użytkowe, kulturowe i ekologiczne. Standardy urbanistyczne powinny zawierać zasady i parametry zagospodarowania i kształtowania zabudowy w zgodzie z zasadami zrównoważonego rozwoju. Powinny być przestrzegane przy formu- 
łowaniu polityk przestrzennych i strategii rozwoju, sporządzaniu planów zagospodarowania i planów inwestycyjnych, jak też przy planowaniu finansowym [3].

\section{Badania literaturowe}

Przez blisko 30 lat nie stosowano w Polsce jakichkolwiek normatywów urbanistycznych - wręcz negowano potrzebę i zasadność ich wykorzystywania. Dotychczasowe prace nad standardami urbanistycznymi, ukierunkowanymi na zapewnienie odpowiedniej jakości środowiska mieszkaniowego zwłaszcza w miastach nie przyniosły jednolitych rozstrzygnięć [4].

Współczesne budowanie miast odbywa się poprzez zmianę użytkowania gruntów oraz politykę promującą m.in.: strefowanie i wyższe stopnie dostępności, intensyfikację, konsolidację lub zagęszczanie struktury urbanistycznej (szczególnie wokół przedmieść), rozwój i rewitalizację poprzemysłowych części miasta, zwiększanie intensywności wykorzystania gruntów podział i przebudowę istniejącej zabudowy, zwiększanie gęstości zamieszkania i re-urbanizację [5], [6]. Miasto wg definicji Zipsera to "system funkcji, instytucji i odpowiadających im trwałych urządzeń materialnych, powstały jako efekt dążeń do uzyskania stanu równowagi przy określonym poziomie selektywności potrzeb i ustalonym układzie wzajemnej dostępności przestrzennej" [7]. Zatem stan równowagi jest zależny od polityki decyzji przestrzennych. Decyzje łatwiej podejmuje się w oparciu o wiedzę i symulowany model, który wspierają badania m.in. parametrów i wskaźników.

W świecie tego typu badania prowadził m.in. Wang, a jego parametr określony jako ecological carrying capasity odzwierciedla stopień oporności ekosystemu spełniającego wymagania rozwijającego się społeczeństwa i gospodarki regionalnej bez zmniejszania zasobów i jakości środowiska ekologicznego. W celu uproszczenia obliczeń analitycznych Wang zaproponował metodę pomiarową opartą na prawie równowagi między podażą i popytem. Ta metoda buduje zestaw wskaźników, w tym indeks systemu społeczno-gospodarczego oraz systemu ochrony środowiska (uwzględniając zasoby i jakość środowiska) [8].

Youpeng Xu zbudował zestaw indeksów i metodę obliczeniową, która nadaje się do kompleksowego szacowania chłonności zasobów wodnych. Określił przy tym, że stan graniczny chłonności zasobów dokładniej ocenia stan pojemności, który uwzględnia czynnik czasu, ale jak to zauważył, jest trudny do obliczenia ponieważ ma krzywoliniową budowę powierzchni.

W Polsce badania chłonności wykonywane są zazwyczaj przy określaniu warunków i zasobów turystycznych i dotyczą one siedlisk roślinnych. Wykonywali je m.in.: Graja-Zwolińska, której badania ukazały znikomą praktyczną wartość wskaźnika, wyznaczanego w oparciu o istniejące sposoby. Podkreśliła, że celowe i konieczne jest opracowanie uniwersalnego (dla określonych ekosystemów) a zarazem kompleksowego (uwzględniającego komponenty świata flory 
jak i fauny) wskaźnika chłonności lecz wypracowanie takiego modelu wymaga ścisłej współpracy specjalistów z wielu dziedzin [9].

Czasem określenie chłonności naturalnej proponuje się metodą opartą na określonych parametrach związanych $\mathrm{z}$ waloryzacją najważniejszych siedlisk roślinnych. Wyznacza się tzw. obciążenie graniczne np.: runa tj. średnią liczbę osób, które poruszając się w ciągu 8 godzin po powierzchni 1 ha mniej więcej jednorodnego płatu roślinności powodują uruchomienie procesów degradacyjnych, zmieniających trwale skład i strukturę biocenozy [10], [11]. Powyżej obciążenia granicznego załamuje się równowaga, w jakiej znajduje się fitocenoza od wpływem antropopresji.

\section{Wskaźniki i parametry urbanistyczne: chłonność, koncentracja, pojemność}

Chłonność jest relacją według określonych reguł kontaktu i konfliktu. Definicja chłonności wg Zipsera oznacza "najwyższą możliwą wielkość strat wynikłych z zagrożenia na tym obszarze - przykładowo: całkowitego zniszczenia pokrywy leśnej lub zupełnego zanieczyszczenia zbiorników wodnych" [7]. Kluczowym jednak wydaje się dobór jednostki przestrzennej, dla której wymiarowaniem powinny być wymierne wskaźniki intensywności elementów relacji zakłócających lub krytycznych. W obecnym stanie planowania przestrzennego w Polsce brak zachowania i jednolitego doboru jednostek przestrzennych (w planowaniu regionalnym, i lokalnym, na poziomie studium uwarunkowań i kierunków zagospodarowania przestrzennego gminy oraz miejscowego planu zagospodarowania przestrzennego) uniemożliwia bilansowanie wartości. Jednym ze składników wskaźnika mógłby być wymiar finansowy lub czas ukazujący nakład środków koniecznych do odbudowy lub przywrócenia stanu początkowego.

Chłonność i pojemność są pojęciami zależnymi. Im większa chłonność systemu czyli jego odporność na zmiany destrukcyjne, tym bardziej może wzrosnąć pojemność układu. Przez pojemność rozumie się maksymalną liczbę osób, które mogą jednocześnie przebywać na danym obszarze, po jego przystosowaniu do tego celu, w warunkach prawidłowego zaspokajania ich potrzeb, bez negatywnych konsekwencji. Chłonność i pojemność najczęściej wyraża liczba osób na ha lub $\mathrm{km}^{2}$, a na terenach gdzie ruch odbywa się liniowo, tylko po wyznaczonych szlakach, wyrażana jest ona liczbą osób na metr lub kilometr bieżący drogi. Warto dodać, iż z chłonnością np.: turystyczną związane są także dwa równie istotne terminy: przepustowość (odnosząca się do szlaków turystycznych) oraz pojemność (dotycząca infrastruktury) [9].

Na zasadzie podobieństwa można w teorii osadnictwa wyróżnić zagadnienie koncentracji, które wg Zipsera jest kluczowe w procesach modelowania struktur zagospodarowania przestrzennego [7]. Podobnie, jak dla chłonności i pojemności, koncentrację można liczbowo wymiarować na wybranym obszarze. Do badania tego zjawiska Zipser wykorzystał krzywą Lorenza, którą wyko- 
rzystuje się do obrazowania nierównomierności gęstości zaludnienia w podjednostkach terenowych. Wydaje się jednak, że od przyjmowanego jednowymiarowego rozkładu zmiennej losowej o wartościach nieujemnych, znacznie lepiej sprawdzą się krzywe wykładnicze, które przy użyciu wnioskowania rozmytego umożliwią skonstruowanie ram interpretacyjnych dla wielowymiarowych danych, gdzie linia prosta będzie aproksymowała gęstość proporcjonalną występowania elementów badanych w jednostkach podziału. Funkcja:

$$
y=f(x)
$$

Funkcja aproksymacyjna zmieni się na wykładniczą kwadratową przy zwiększaniu się koncentracji modelu struktury przestrzennej aż do wykładniczej trzeciego i dalszego stopnia:

$$
y=f\left(x^{3}\right)
$$

Prawidłowość koncentracji, zgodnie z teorią osadnictwa i planowania przestrzennego, zakłada nierównomierność rozmieszczenia elementów (także ludności) w zależności od kilku czynników, w tym:

- przyrodniczo - geograficznych (klimat, rodzaj gleby, ukształtowanie terenu, zasoby mineralne i energetyczne),

- społeczno - ekonomicznych (stopień rozwoju społeczno - ekonomicznego, formy społecznej organizacji, rozwój techniki),

- demograficznych (zróżnicowanie rodności i umieralności na różnych obszarach, migracje) [7].

Podstawowe czynniki, determinujące rozmieszczenie ludności, są zatem funkcją wielowymiarową, zbieżną z regułą podziału Clarka o proporcjonalnie malejącej gęstości do odległości od centrum zjawiska. Współczynnik gęstości zaludnienia - obliczany jest jako stosunek liczby ludności do powierzchni badanego terytorium. Ponadto, przy intensywnym zagospodarowaniu stosuje się wskaźniki normatywne, choć pod uwagę brane są w większym stopniu aspekty psychologiczno-socjalne niż przyrodnicze. Badania cechuje duża doza subiektywizmu i rozpiętości ocen.

Można zatem, z dużą dozą prawdopodobieństwa, określić, że pojemność jest funkcją koncentracji i chłonności $\mathrm{w}$ danych jednostkach przestrzennych. Zależność tę można zamodelować np.: z użyciem sztucznej inteligencji lub oprzeć na wnioskowaniu z jej udziałem.

Sztuczne sieci neuronowe, ze względu na ich nieliniowy charakter, reprezentują wyrafinowaną technikę modelowania i są zaliczane do metod inteligencji obliczeniowej. Funkcje pełnione przez sieć pozwalają uzyskać korzystne wyniki w zastosowaniach praktycznych dla takich zagadnień jak: aproksymacja, interpolacja, rozpoznawanie i klasyfikacja wzorców, kompresja, predykcja i wiele innych. Sieć neuronowa $w$ tych i innych zastosowaniach stanowi uniwersalny układ aproksymacyjny, który jest w stanie zrealizować funkcję nieliniową wielu zmiennych postaci [18]: 


$$
\mathbf{y}=f(\mathbf{x})
$$

gdzie $\mathbf{x}$ oznacza wektor wejściowy, $\mathbf{y}$ zaś realizowaną funkcję wektorową w całym zbiorze nieokreśloności, której transformacja odbywa się z zastosowaniem funkcji aktywacji. Wiele zastosowań sieci neuronowych sprowadza się do problemów aproksymacji w przestrzeniach wielowymiarowych. Sieci neuronowe doskonale sprawdzają się wszędzie również tam, gdzie do opisu zjawisk nie znajduje zastosowania aproksymacja liniowa, ponieważ tworzone z zastosowaniem sieci neuronowych modele bez trudu odwzorowują zależności nieliniowe.

Biorąc pod uwagę tematykę poruszaną w artykule, celowym wydaje się zastosowanie sieci neuronowych (w szczególności perceptronu wielowarstwowego) do zamodelowania zależności pomiędzy chłonnością, koncentracją a pojemnością terenów miejskich. Perceptron wielowarstwowy, jest to sieć neuronowa jednokierunkowa wielowarstwowa, a poszczególne klasy tego typu sieci różnią się definicją funkcji aktywacji $f(n e t)$. Sieć neuronowa uczy się wytwarzać określony poziom aktywacji, a nie wartości ekstremalne, które są trudne bądź niemożliwe do wytworzenia. W sieciach neuronowych zbudowanych z neuronów ciągłych (neuron typu sigmoidalnego) stosuje się najczęściej nieliniowe funkcje aktywacji:

- funkcja bipolarna (tangens hiperboliczny)

$$
y=f(\text { net })=\tanh \left(\lambda_{\text {net }}\right)=\frac{1-\exp \left(-\lambda_{\text {net }}\right)}{1+\exp \left(-\lambda_{\text {net }}\right)} \quad \lambda>0,
$$

- funkcja unipolarna (funkcja logistyczna)

$$
y=f(\text { net })=\frac{1}{1+\exp (-\lambda \text { net })} \quad \lambda>0
$$

gdzie: $n e t \stackrel{d e f}{=}\left[\mathbf{w}^{T} \mathbf{x}\right]$ - sygnał wyjściowy liniowej części neuronu będący iloczynem skalarnym wektorów wag i wejść, $\lambda$ współczynniki nachylenia funkcji aktywacji (skos).

\section{Zielona Góra}

Miasto Zielona Góra, na prawach powiatu, dawniej stolica województwa zielonogórskiego, dziś siedziba władz samorządowych województwa lubuskiego, z dniem 01 stycznia 2015 r. powiększyła swoją powierzchnię terytorialną o przyległą gminę wiejską. Dzięki temu uzyskała szóstą pozycję w klasyfikacji, biorąc pod uwagę powierzchnię miast Polski w ich granicach administracyjnych. Połączenie miasta średniej wielkości, o średniej intensywności i gęstości zabudowy z terenami gminy wiejskiej charakteryzującymi się niską intensywnością, 
niesie ogromne ryzyko niekontrolowanego zwiększenia powierzchni zabudowanej. W ostatnich latach, wraz z gwałtownym rozwojem przestrzennym, nastąpiły różne formy zamiany użytkowania terenów. Najgroźniejsze wydają się jednak zmiany użytkowania lasów ochronnych na tereny inwestycyjne, w tym mieszkaniowe. W 1998 r. lasy, w granicach administracyjnych miasta, stanowiły 740 ha, dla porównania w 2008 r. już tylko 557 ha $^{2}$. Ponad 80\% powierzchni tych terenów stanowią lasy ochronne - najczęściej wodonośne. W ciągu zaledwie 10 lat wycięto prawie 200 ha lasów. Od 2002 do 2014 roku, pomimo nasadzeń ubyło z przestrzeni miasta 2158 drzew i 1434 krzewy $^{3}$. Niestety, nie usprawiedliwia tego faktu ani chęć zwiększenia liczby mieszkańców, ani poprawa standardu zamieszkiwania [12].

W dokumentach strategicznych, rozwój miasta Zielona Góra został oparty na scenariuszu „maksymalnego chłonnościowego” wykorzystania istniejącego potencjału terenów, z jednoczesnym zachowaniem zasad i warunków zrównoważonego rozwoju. Zakłada on także przyjęcie wieloletniej spójnej polityki ochrony, gospodarowania i zarządzania terenami leśnymi. Miejskie dokumenty programowe najczęściej odnoszą się w zapisach do konieczności: zachowania systemów zieleni, przeciwdziałania antropopresji, polepszania stanu zasobów krajobrazowych oraz „zwiększania atrakcyjności środowiska przyrodniczego, jako elementu wizerunku miasta oraz czynnika przyciągającego turystów i inwestorów" [13,14,15,16,17].

W wyniku przedkładania doraźnego interesu inwestorów nad dobro mieszkańców, w ostatnich latach nasiliło się między innymi zjawisko niekontrolowanej fragmentacji cennych terenów otwartych przestrzeni miejskich [12]. Widać to doskonale przy porównaniu dokumentów planistycznych z lat 2000 i 2008 dla miasta Zielona Góra. W 2000 roku Zielona Góra była otoczona zielonym pierścieniem lasów, który przecinał promieniście poprowadzony układ komunikacyjny z zewnętrznymi pierścieniami i zewnętrzną półobwodnicą dostosowaną do funkcji przyspieszonego ruchu. Wraz z nową zmianą studium w 2008 roku, pierścienie dróg obwodowych zostały zamienione na wewnętrzne ulice i obudowane terenami komercyjnymi, podobnie jak obwodnica o przyspieszonym ruchu ,Trasa Północna". Obecnie droga ta pełni rolę bariery rozdzielającej osiedle mieszkaniowe o dużej intensywności. Pierścień zieleni zmienił się w płaty lasu poszatkowane formami niskointensywnej zabudowy.

\footnotetext{
${ }^{2}$ Dane GUS za 2008 rok. Bank danych lokalnych.

${ }^{3}$ Dane GUS za 2014 rok. Bank danych lokalnych. Nasadzenia i ubytki drzew i krzewów w gminach.
} 


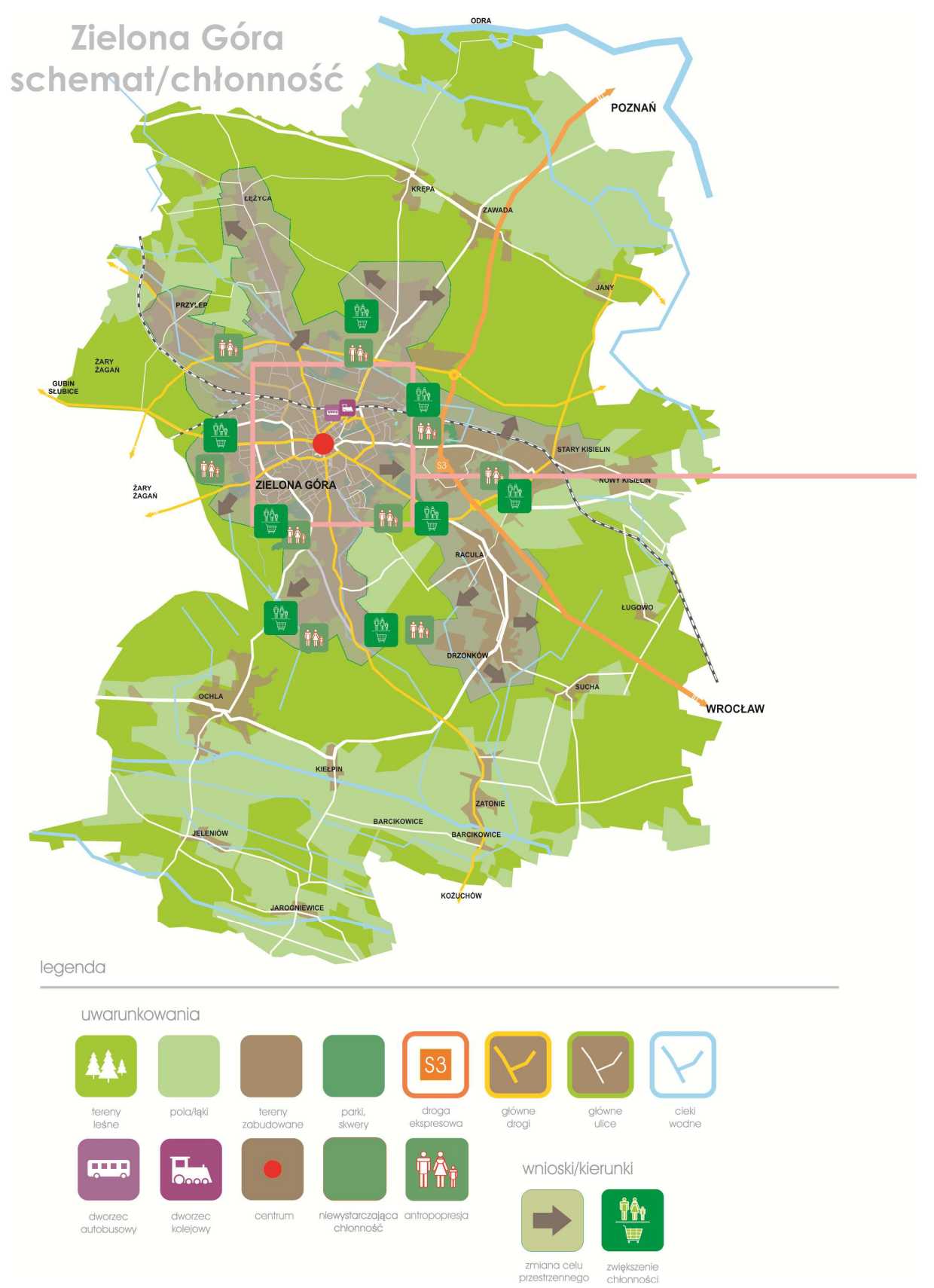

Rys. 1. Schemat terenów otwartych, lasów i parków leśnych w granicach administracyjnych Zielonej Góry

Fig. 1. Scheme of open areas, forests and forest parks in the administrative boundaries in Zielona Góra 


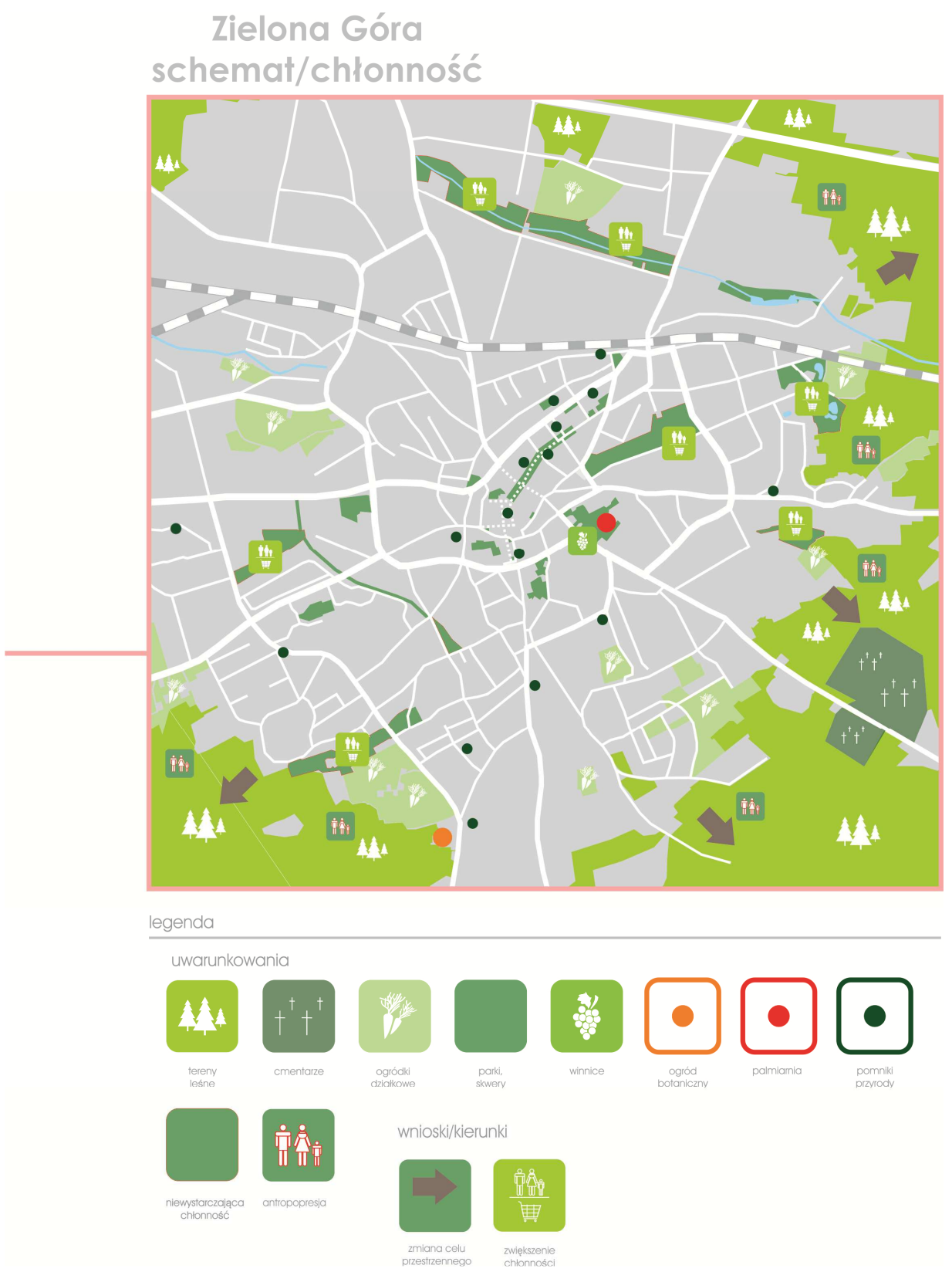

Rys. 2. Schemat terenów zieleni w mieście Zielona Góra

Fig. 2. Scheme of green areas in the town Zielona Góra 


\section{Wnioski}

Konieczność monitoringu i kontroli polityki zagospodarowania przestrzennego mimo, że wymuszona ustawowo w ramach ustaleń ustawy z dnia 27 marca 2003 roku o planowaniu i zagospodarowaniu przestrzennym, nie wskazuje jednolitego zestawu wymaganych standardowych wskaźników urbanistycznych, które umożliwiłyby jakiekolwiek bilansowanie wartości w jednostkach przestrzennych. Widoczna jest potrzeba ujęcia ich w spójnym i kompletnym zbiorze regulacji. Kontynuacji i uszczegółowienia wymagają studia nie tylko nad intensywnością zabudowy, ale także nad chłonnością, pojemnością i koncentracją jako parametrami będącymi w zależności. Niewątpliwie wskaźniki zbudowane na podstawie tych parametrów powinny uwzględniać skalę miasta, a także położenie obszaru w strukturze miasta.

We współczesnym świecie miasto musi oferować na tyle atrakcyjne środowisko mieszkaniowe, żeby powstrzymać ucieczkę mieszkańców do domku pod miastem i niekontrolowany, nieekonomiczny i szkodliwy dla środowiska naturalnego rozwój suburbii. Dlatego niezbędne jest - właśnie poprzez standardy urbanistyczne - zapewnienie konkurencyjnych wartości przestrzeni miasta poprzez łatwy dostęp do terenów zieleni o wysokich walorach przyrodniczych, rekreacji i sportu, a także stworzenie warunków obcowania z naturą w najbliższym otoczeniu miejsca zamieszkania. Nie da się tego osiągnąć bez możliwości symulacji rozwiązań w skali miasta. Decyzje planistyczne dotyczące zagospodarowania miasta, powinny zapadać w oparciu o wiedzę i sprawdzalne wskaźniki regulacyjne, a nie w następstwie indywidualnych decyzji realizowanych na poziomie jednostek samorządowych, na doraźne potrzeby inwestorów.

\section{Literatura}

[1] Kopietz-Unger J.: Założenia planowania przestrzennego na rzecz ochrony klimatu i oszczędności energii, Oficyna Wydawnicza Uniwersytetu Zielonogórskiego, Zielona Góra, 2010.

[2] Śleszyński P., Komornicki T., Deręgowska A., Zielińska B.: Analiza stanu i uwarunkowań prac planistycznych w gminach w 2013 roku. https://www.mr.gov.pl/ media/5139/analiza_2013.pdf. (dostęp: 16.02.2016 r.).

[3] Polska Polityka Architektoniczna. Polityka jakości krajobrazu, przestrzeni publicznej, architektury - dokument opracowany z inicjatywy Polskiej Rady Architektury, Stowarzyszenia Architektów Polskich pod patronatem Ministerstwa Kultury i Dziedzictwa Narodowego przez reprezentantów ZG SARP, ZG TUP, Krajowej Izby Architektów RP, Polskiej Rady Architektury, środowiska architektów krajobrazu oraz Krajowego Ośrodka Badań i Dokumentacji Zabytków, 2008, s. 5. http://www.sarp.org.pl (dostęp: 16.02.2016 r.).

[4] Dąbrowska-Milewska G.:Standardy urbanistyczne dla terenów mieszkaniowych wybrane zagadnienia. Architecturae et Artibus, no. 1, 2010, pp. 17-31. 
[5] Schwarz N., 2010. Urban form revisited-Selecting indicators for characterising European cities, Landscape and Urban Planning, no. 96, pp 29-47.

[6] Bazan - Krzywoszańska A.: Rozwój społeczno-przestrzenny Zielonej Góry po 1945 roku. Dynamika rozwoju od miasta małego do miasta średniej wielkości, Oficyna Wydawnicza Uniwersytetu Zielonogórskiego, Zielona Góra 2013.

[7] Zipser T.: Zasady planowania przestrzennego, Oficyna Wydawnicza Politechniki Wrocławskiej, Wrocław 1983.

[8] Wang X., 2010. Research Review of the Ecological Carrying Capacity, Journal of Sustainable Development, vol. 3, no. 3, pp. 263-265.

[9] Graja-Zwolińska S.: Rola wskaźnika chłonności turystycznej w kształtowaniu przestrzeni turystycznej parków narodowych, Studia i Materiały Centrum Edukacji Przyrodniczo-Leśnej R.11. Zeszyt 4 (23) 2009, s.187-192.

[10] Kostrowicki, A.: Metoda określania odporności roślin na uszkodzenia mechaniczne powstałe na skutek wydeptywania, Prace IGiPZ PAN, 139, Wydawnictwo Ossolińskich, 1981.

[11] Leśniak M.: Projekt strefowania turystyki w Parku Krajobrazowym Doliny Baryczy, Biblioteka Doliny Baryczy, 2009.

[12] Skiba M, Bazan-Krzywoszańska A., Polityka przestrzenna Zielonej Góry źródłem zagrożeń dla zrównoważonego rozwoju miasta, Czasopismo Techniczne: Architektura, r. 107, z.14, 2010, s. 143-152.

[13] Studium uwarunkowań i kierunków zagospodarowania przestrzennego Zielonej Góry, uchwała Nr XXIV/256/2000, Rada Miejska w Zielonej Górze, Zielona Góra 2000.

[14] Zmiana studium uwarunkowań i kierunków zagospodarowania przestrzennego Zielonej Góry, uchwała Nr XXVIII/392/08, Rada Miasta Zielona Góra, Zielona Góra 2008.

[15] Zmiana studium uwarunkowań i kierunków zagospodarowania przestrzennego Zielonej Góry, uchwała Nr III/19/10, Rada Miasta Zielona Góra, Zielona Góra 2010.

[16] Zmiana studium uwarunkowań i kierunków zagospodarowania przestrzennego, uchwała nr LXIV.556.2014, Rada Miasta Zielona Góra , Zielona Góra 2014.

[17] Zmiana studium uwarunkowań i kierunków zagospodarowania przestrzennego, uchwała nr LXVIII.599.2014, Rada Miasta Zielona Góra, Zielona Góra 2014.

[18] Osowski S.: Sieci neuronowe do przetwarzania informacji. Oficyna wydawnicza Politechniki Warszawskiej, Warszawa 2000.

\section{ABSORBENCY GREEN AREAS IN THE CITY - CASE STUDY OF ZIELONA GÓRA}

\section{S u m m a r y}

The article presents an attempt to draw attention to the missing standards for urban areas. Indicators which were analyzed to estimate the absorbency of the land needed for programming public recreation areas. Presented literature related indicators absorbency of land, which are used to establish links between the intensity and density of buildings around the area of biologically active - forests, parks and lawns. Also presented possibilities for use of modeling by means of artificial neural networks for evaluation absorbency and the capacity of urban areas. The article 
presented the basics theoretical possible to use in experimental work, help in determining the factors and elements influencing factors urban. Research absorbency of green areas in cities will affect the conservation of biodiversity within the urban environment of cities. The article can help in identifying problems in the policy of sustainable development of urban areas. Writing in the local urban planning documents (master plan) should stand out and protect urban green areas, taking into account the limits of their absorbency and capacity. Necessity monitoring and control of spatial planning policy, although Forced by statute in the context of the findings of the Act of 27 March 2003 for spatial planning and development, does not indicate uniform set the required standard of urban indicators, which allow any balancing of the spatial units. Visible is the need to recognize them in a coherent and complete set of regulations.

Keywords: capacity, concentration, urban indicators, city, artificial neural networks

Przestano do redakcji: $30.08 .2016 r$.

Przyjęto do druku: 15.09.2016 r.

DOI: $10.7862 / \mathrm{rb} .2016 .140$ 